\title{
Characterization and influence of subtropical persimmon cultivars on juice and jelly characteristics
}

\author{
PAULA N. CURI ${ }^{1}$, BRUNA S. TAVARES ${ }^{2}$, ALINE B. ALMEIDA ${ }^{2}$, RAFAEL PIO ${ }^{1}$, \\ MOACIR PASQUAL ${ }^{1}$, PEDRO M. PECHE ${ }^{1}$ and VANESSA R. SOUZA ${ }^{2}$ \\ ${ }^{1}$ Departamento de Agricultura, Universidade Federal de Lavras, Av. Doutor Sylvio \\ Menicucci, 1001, Kennedy, 37200-000 Lavras, MG, Brazil \\ ${ }^{2}$ Departamento de Ciência dos Alimentos, Universidade Federal de Lavras, Av. Doutor \\ Sylvio Menicucci, 1001, Kennedy, 37200-000 Lavras, MG, Brazil
}

Manuscript received on February 23, 2016; accepted for publication on November 8, 2016

\begin{abstract}
To increase the availability to consumers and add more value to persimmon (Diospyros kaki L.), which is a very perishable and seasonal fruit and in order to identify which cultivars grown in subtropical regions are more suitable for processing in the form of juice and jelly, as well as understand what the consumer profile is for these products, the objective of this study was to evaluate the influence of different persimmon cultivars (Rama Forte, Mel, Guiombo and Taubaté) grown in subtropical regions of Brazil on the physicochemical characteristics, rheological properties and sensory acceptance of the resulting juice and jelly in order to identify cultivars with the greatest potential for industrial use. The different studied persimmon cultivars had different physical and physicochemical characteristics which resulted in juices and jellies with different physicochemical, rheological and sensory characteristics. Based on sensory acceptance and productivity/ adaptability of persimmon crop in Brazil, the most suitable persimmon cultivars for processing are Rama Forte and Guiombo. In this study it was found that the consumer prefers a more acidic persimmon juice and a less firm or softer, less sweet, clearer and more intense yellow color persimmon jelly.
\end{abstract}

Key words: persimmon, subtropical, jelly, juice, processing.

\section{INTRODUCTION}

The persimmon (Diospyros kaki L.) is a fruit native to Asia, traditionally grown in temperate and subtropical climates (Martineli et al. 2013, Del Bubba et al. 2009) Persimmon has a good commercial acceptance because of its appearance, aroma and attractive flavor and can be eaten fresh or

Correspondence to: Vanessa Rios de Souza

E-mail: vanessardsouza@gmail.com in processed form. In addition to, the organoleptic characteristics, the persimmon is a fruit that has beneficial health properties, as it contains high amounts of phenolic compounds including polyphenols, carotenoids, has high antioxidant capacity and is also a source of fiber, vitamins and minerals (Veberic et al. 2010, Nugraheri et al. 2013, Jiménez-Sánchez et al. 2015).

The Brazilian production of persimmons has grown in recent years, compared to the high yields 
that this fruit tree provides (Brackmann et al. 2013). The state of São Paulo, with more than 8,100 ha in production, has the largest cultivated area in Brazil (Alves et al. 2011) and the main persimmons grown are the cultivars 'Rama Forte', 'Mel', 'Guiombo' and 'Taubaté' (Pio et al. 2003, Tessmer et al. 2014). The persimmon cultivars, of Japanese origin, can be classified into three basic types: tannic ("sibugaki"), variable ("sibugaki variant" or "variant amagaki") and sweet ("amagaki") (CampoDall'Orto et al. 1996, Blum et al. 2008). The Rama cultivar is astringent and features high levels of soluble tannins as its main characteristic, making them unsuitable for fresh consumption (Edagi et al. 2009, Gardin et al. 2012). The Giombo is classified by Ito (1971) as belonging to the astringent and constant pollination type. However, Martins and Pereira (1989) cite it as belonging to the variable type, with fruit pulp with sufficient tannin when parthenocarpic, and the "chocolate" type without astringency when with numerous seeds. Since they are mostly consumed fresh, the fruits of astringent cultivars require removal of the astringency prior to consumption (Edagi and Kluge 2009, Terra et al. 2014).The cultivar Taubaté features large and globular fruit, but has a film cracking tendency and the defect to quickly soften after astringency before that, the fruit of this cultivar are mainly used for industrial processing. This cultivar belongs to the tannin group and are yellow in color when ripe and may have seeds. Cultivar Mel presents a huge potential to be grown in subtropical and tropical regions, the fruit rind is yellowish when ripe with orange pulp and may present seeds (Bueno et al. 2014).

Whatever the cultivar, the fruit of the persimmon has a lot of pulp, with high concentration of antioxidants such as vitamins $\mathrm{A}$ and $\mathrm{C}$ (ascorbic acid) and polyphenols (Veberic et al. 2010), but this composition can influence the characteristics of the products obtained after processing. Recently studies with different persimmon cultivars shown that the cultivar influences the physicochemical, rheological and sensory characteristics (JiménezSánchez et al. 2015) as well as antioxidant activity and bioactive compounds of the jellies and juices (Lee et al. 2012, Butt et al. 2015).

The persimmon harvest is concentrated in three months of the year. The lack of consistent information on the storage and transport factors limits the expansion of the crop, leading to losses at the end of the production process as well as during the marketing of the fruit (Vieites et al. 2012). Although consumed fresh, losses that occur during persimmon storage are, to a large extent due to excessive ripening, loss of firmness, rot and the incidence of fruit peel browning. The fresh fruits are highly perishable and there are several problems related to their conservation, originating at harvest time when a series of processes begin that influence the quality of the product and its consequent loss. The induced acceleration of maturity, commonly conducted to promote the astringency of the persimmon fruits, further contributes to the shelf life reduction (Edagi and Kluge 2009). Thus, one way to increase the availability to the consumer, and even provide more value to the end product, is processing or industrialization, through jams, jellies, juices, dried persimmon and vinegar (González et al. 2015).

Persimmon is classified as a low-acid fruit, presenting titratable acidity in malic acid around $0.16 \%$ to $0.23 \%$ (González et al. 2015). So, it reinforces that the fruits can be used for the production of juices and high quality jellies and jams, but for that one should check if there are any cultivar that provides these processed foods with greater organoleptic quality.

In this context, the objective of this study was to evaluate the influence of different persimmon cultivars (Rama Forte, Mel, Guiombo and Taubaté) grown in subtropical regions of Brazil as to their the physicochemical characteristics, rheological properties and sensory acceptance of the resulting 
jelly and juice in order to identify cultivars with the greatest potential for industrial use.

\section{MATERIALS AND METHODS}

\section{INGREDIENTS}

The jellies and juices were prepared from four persimmon cultivars; Rama Forte, Mel, Guiombo and Taubaté. These cultivars were harvested in the morning in São Bento do Sapucaí, São PauloBrazil, at their physiological maturity, determined by color and fruit size, and were immediately transported to the Post Harvest Laboratory of the Federal University of Lavras, Minas Gerais-Brazil and cold-stored until processing time. In addition to the fruit, sucrose, high-methoxyl pectin (Danisco, SP, Brazil) and citric acid (Vetec, SP, Brazil) was used for the preparation of the jellies. To prepare the juice only the fruit and the sweetener, sucralose, was used. In pre-tests, it was found that the persimmon juice sweetened with sucralose showed the most pronounced and pleasant persimmon flavor than the juice made with sugar, for this reason, it was decided to prepare the diet juice.

\section{JUICE AND JELLY PROCESSING}

Four persimmon jellies and juices were prepared and the variation between the formulations was only the persimmon cultivar. The preparation of the jelly and juice was conducted in the Plant Product Processing Laboratory.

After the discard of the fruit with physical or microbiological damage and manual removal of the leaves, the persimmons were washed in potable water. To obtain the pulp used in the juice and jelly preparation, the fruits were homogenized with $30 \%$ water for about $5 \mathrm{~min}$ in an industrial Poly. LS-4 blender with a $4 \mathrm{~L}$ capacity at a $3500 \mathrm{rpm}$ (Metalúrgica Siemsen Ltda, Brusque, Brazil).

For the juice preparations $0.0275 \%$ of sucralose was added to the obtained fruit pulp. The juice was then homogenized, subjected to heat treatment at $90^{\circ} \mathrm{C} / 30 \mathrm{~s}$ and then bottled in $500 \mathrm{~mL}$ sterilized glass bottles. The juice was stored under refrigeration at between $4-8^{\circ} \mathrm{C}$ until analysis $(12$ to $24 \mathrm{~h}$ ). No preservative was added to the product, because the sensory and physicochemical analyzes were performed within $48 \mathrm{~h}$ after processing.

To elaborate the jellies the pulp obtained was finely sieved to obtain the clarified juice. The percentages of ingredients used for preparation of the jellies were $60 \%$ clarified persimmon juice, $40 \%$ sugar, $1.5 \%$ high methoxyl pectin and $6.0 \%$ citric acid (2\%). For the preparation of jellies, sugar was added in the fruit pulp and then the processing was carried out in an open pan heated by a gas flame (Macanuda, SC, Brazil). After boiling, pectin was added. At the end of the process, when the soluble solids reached $65^{\circ} \mathrm{Brix}$, heating was stopped and the citric acid was added. The total soluble solids were determined using an RT-82 portable refractometer. The hot jellies were poured into sterile $250 \mathrm{~mL}$ glass vials and stored at $7^{\circ} \mathrm{C}$ until analysis (12 to $24 \mathrm{~h}$ ).

\section{PHYSICAL AND PHYSICOCHEMICAL ANALYSIS}

To characterize the different persimmon cultivars, the analysis of total soluble solids, total acidity, $\mathrm{pH}$, color $\left(L^{*}, a^{*}\right.$ and $\left.b^{*}\right)$, length, diameter, mass and texture was made in the fresh fruits. In the jellies and juices, total soluble solids, $\mathrm{pH}$, total acidity and color ( $\mathrm{L}^{*}, \mathrm{a}^{*}$ and $\left.\mathrm{b}^{*}\right)$ analyses were conducted. A texture profile analysis (TPA) was also carried out in the various jelly formulations obtained. The analyses were performed in the Post Harvest Laboratory in three repetitions.

The total acidity, soluble solids and $\mathrm{pH}$ values were determined according to IAL (2005). The method proposed by Somogy and adapted by Nelson (1944) was used in order to determine total sugars and reducing sugars. The $\mathrm{L}^{*}, \mathrm{a}^{*}$ and $\mathrm{b}^{*}$ values were determined using a Minolta CR 400 colorimeter (Konica Minolta, São Paulo, Brazil) 
with standards and D65 CIELab, where L* ranges from 0 (black) to 100 (white), a* is green (-) to red $(+)$ and $b^{*}$ is blue (-) to yellow (+) (Gennadios et al. 1996).

For conducting fruit firmness, we measured the force required for a $3 \mathrm{~mm}$ probe coupled to a digital penetrometer, Instrutherm PTR-300, to overcome the resistance of the fruit pulp. The determinations were performed at two separate points on the fruit and the results expressed in Newtons $(\mathrm{N})$.

The length and diameter of fruit were measured with the aid of a digital caliper $150 \mathrm{~mm}$ (Kingtools, São Paulo, SP), and average fruit weight was determined by individual weighing of each fruit with the aid of a AUX220 semi - analytical scale, (Shimadzu of Brazil, São Paulo, SP).

The texture profile analyses (TPA) of the jellies were performed in penetration mode under the following conditions: a pre-test speed of $1.0 \mathrm{~mm} / \mathrm{s}$, a test speed of $1.0 \mathrm{~mm} / \mathrm{s}$, a posttest speed of $1.0 \mathrm{~mm} / \mathrm{s}$, a time interval between penetration cycles of $10 \mathrm{~s}$, a distance of 40.0 $\mathrm{mm}$ and a compression with a $6.0 \mathrm{~mm}$ diameter cylindrical aluminum probe using a Stable Micro Systems TA-XT2i texturometer (Goldaming, England). The jelly samples were compressed by approximately $30 \%$. The parameters analyzed were hardness, adhesiveness, springiness, cohesiveness, gumminess and chewiness (Friedman et al. 1963, Bourne 1968, Van Vliet 1991).

\section{BIOACTIVE COMPOUNDS AND ANTIOXIDANT ACTIVITIES}

\section{Total phenolics}

Total phenolics determination was carried out according to Singleton et al. (1999), using $0.25 \mathrm{~mL}$ of the extracts obtained and adding them to $2 \mathrm{~mL}$ of distilled water and $0.25 \mathrm{~mL}$ of Folin-Ciocalteu. The total phenolics content was calculated using the standard curve of gallic acid. The results obtained were expressed in mg of gallic acid per 100 gram sample.

\section{Antioxidant Activity}

DPPH: The antioxidant capacity was determined through the reduction of DPPH (2,2-diphenyl-1picrylhydrazyl) (Sigma ChemicalCo.,St.louiz, USA) by the antioxidant present in the sample; a method proposed by Brand-Williams et al. (1995) with a few modifications (Duarte-Almeida et al. 2006). The results were expressed in percentage of sequestration.

$\beta$-carotene/linoleic acid: The preparation of the $\beta$-carotene/linoleic acid system required $50 \mathrm{~mL}$ of $\beta$-carotene diluted in chloroform $\left(20 \mathrm{mg} \mathrm{mL}^{-1}\right)$, $40 \mu \mathrm{L}$ of linoleic acid and $530 \mu \mathrm{L}$ of Tween-40, and $1 \mathrm{~mL}$ of chloroform. The chloroform was evaporated in a rotary evaporator; then $100 \mathrm{~mL}$ of oxygen-saturated water was added and agitated until it reached an absorbance of $0.6 \mathrm{~nm}$ to 470 $\mathrm{nm}$ at which time the solution presented a yelloworange coloration. Three control-tubes were prepared and each consisted of $5 \mathrm{~mL}$ of the solution/ system with $0.4 \mathrm{~mL}$ of the Trolox ${ }^{\circledR}$ standard. After homogenization, readings in the spectrophotometer were performed at $470 \mathrm{~nm}$, using the oxygenated water for calibration. The percentage of oxidation inhibition was evaluated, considering that the absorbance reduction of the system in the absence of an antioxidant (Equation 1) represents $100 \%$ of oxidation.

Absorbance reduction $=$ Initial Abs - Final Abs

(Eq. 1)

The reading of the samples absorbance decrease was correlated with the system, and the oxidation percentage was established (Equation 2). The percentage of the protection against lipid oxidation is calculated subtracting the percentage of oxidation of each sample (Equation 3).

$\%$ oxidation $=\frac{[(\text { Abs reduction }) \text { sample } x 100]}{(\text { Abs reduction }) \text { system }}$ 
$\%$ protection $=100-(\%$ oxidation $)$

The antioxidant action of each sample was verified comparing these samples with the antioxidant activity of the substance used in the control group.

\section{SENSORY ANALYSIS}

Sensory analysis was performed in the Sensory Analysis Laboratory. Two sessions of sensory analysis were performed; on the first day the evaluation of the juice formulations was conducted and on the second day, the jelly formulation evaluations. An acceptance test was conducted with 90 consumers per day, in which the evaluated attributes were color, taste, consistency and overall liking, through a 9-point hedonic scale (1 $=$ extremely dislike, $9=$ extremely like) (Stone and Sidel 1993).

Each taster assessed, on average, $5 \mathrm{ml}$ of juice and 5 grams of each of the four persimmon jelly formulations (Acosta et al. 2008), which were served in $50 \mathrm{~mL}$ plastic cups coded with 3 digits in a monadic manner and in a balanced order (Wakeling and Macfie 1995). The test was carried out in individual booths under white light and ventilation. The tasters were instructed in the use of the hedonic scale and to drink water between samples.

The sensory analysis were performed according to the Ethics Committee of the Federal University of Lavras - Lavras, MG (Brazil), approval number 1.091.594. The participants were informed about the sensory tests and provided written consent.

\section{STATISTICAL ANALYSIS}

To compare the persimmon cultivars regarding the physicochemical characteristics and to compare the persimmon jellies and juices regarding the physicochemical, rheological and sensory characteristics, initially a univariate statistical analysis (ANOVA) and Tukey mean test were used to verify if there was a difference between samples at a significance level of $5 \% \mathrm{p} \leq 0.05$.

For better understanding and visualization of sensory acceptance of the samples a multivariate statistical analysis was performed, which considers the individuality of consumers and not only the average consumer group that evaluated the product. PARAFAC procedures for three-way internal preference mapping were performed (Nunes et al. 2011). A three-way array was arranged from stacked matrices (consumer $\mathrm{x}$ samples) of the acceptance attributes. Each individual acceptance matrix of the consumer acceptance attributes was previously standardized (correlation matrix). The PARAFAC model was optimized using the value of core consistency diagnostic (CORCONDIA) for choosing the number of factors (Bro 1997, Nunes et al. 2011).

In order to correlate the consumer acceptance with persimmon juice physicochemical characteristics and with persimmon jelly physicochemical characteristics and texture parameters, external preference mapping was also performed. Data were arranged in a matrix of 4 lines (samples) and 6 columns for juice (physicochemical and texture parameters) and 12 columns for jelly (physicochemical and texture parameters). Data were standardized (correlation matrix) and PCA was applied. After the obtaining the PCA, a regression step was conducted and the first 2 principal components of the PCA scores were fitted against the overall acceptance for each consumer using a vector (linear) model. The external preference map was built by plotting the PCA scores (samples) and loadings (descriptive attributes) from the first 2 principal components and plotting the slopes of the models for the consumers (Souza et al. 2014).

Data analysis was performed with SensoMaker software version 1.6 (Pinheiro et al. 2013). 


\section{RESULTS AND DISCUSSION}

\section{PERSIMMON CULTIVARS}

\section{Physical and physicochemical analysis}

The average values and the average test of the physical and physicochemical properties evaluated for the different cultivars are shown in Table I. The persimmon cultivars showed significant differences $\mathrm{p} \leq 0.05$ for average length, soluble solids, firmness and color parameters $L^{*}, a^{*}$ and $b^{*}$. For the other parameters (average diameter, unit weight, total acidity and $\mathrm{pH}$ ) significant differences were not observed.

Regarding the size and weight parameters of persimmons, from Table I, it can be seen that in the case of the average fruit length, quantified in the direction of the stalk, the Taubaté cultivar differed from the others, as it presented the largest dimension $(69.25 \mathrm{~mm})$, whereas in the other cultivars the range of variation was 49.26 (Rama Forte) to $64.91 \mathrm{~mm}$ (Guiombo). The average diameter and unit weight did not differ among cultivars, and the diameter of persimmons ranged from $59.35 \mathrm{~mm}$ to $68.02 \mathrm{~mm}$ and the unit weight ranged from $111.21 \mathrm{~g}$ to $162.66 \mathrm{~g}$ (Table I). These results agree with other similar works MartínezCalvo et al. (2013), who also found unitary weight between 150 and $160 \mathrm{~g}$ and an average diameter in the range of 65 to $70 \mathrm{~mm}$ in several persimmon cultivars.

In relation to physicochemical parameters, persimmons showed no significant difference for total acidity and $\mathrm{pH}$, and acidity varied 0.06 to $0.08 \mathrm{~g}$ of citric acid / $100 \mathrm{~g}$ fw and the $\mathrm{pH}$ varied from 5.62 to 6.15 (Table I). Acidity is one of the criteria that affect the classification of fruit-based flavor, fruit with acidity levels up to $1.95 \%$ can be classified as mild in flavor and are well accepted for consumption as fresh fruit (Paiva et al. 1997) In general, the persimmon cultivars fall into this category, which can be interesting for fresh consumption. On the one hand, for processing in the form of jams and jellies the addition of acid in the formulation may will be necessary. For the development of products such as jams and jellies, in which gel formation is necessary, higher acidity is desired - the optimum $\mathrm{pH}$ for the preparation of jellies for example, is around 3.5 (Jackix 1988).

The soluble solids content varied significantly among cultivars, ranging from 15.37 to $18.23^{\circ} \mathrm{Brix}$, and the cultivar Guiombo stood out for having the highest soluble solids content (18.23 ${ }^{\circ}$ Brix) (Table I). An important factor for products that are sold and eaten fresh is the content of sugars and organic acids, which are linked to the amount of soluble solids present in the fruit, since consumers prefer sweeter fruits (Silva et al. 2002). Thus, the fruits with a higher possibility of acceptance are those with high levels of soluble solids and total sugars. Thus, it can be seen that the Guiombo cultivar, characterized by presenting the sweetest fruits, can be very interesting for fresh consumption.

Generally, the physicochemical characteristics of $\mathrm{pH}$, total acidity and soluble solids corroborate with the range found in previous studies Blum et al. (2008) and Vieites et al. (2012).

Regarding the fruit firmness, the range of variation was from 71.83 (Taubaté) to $138.5 \mathrm{~N}$ (Mel). The Mel cultivar differentiated from the others, being considered the cultivar that showed the firmest fruits (Table I). Importantly, the difference in the firmness of the cultivars may be due to differences in the fruit maturation stage and not only differences due to cultivar because although great care has been taken, we cannot guarantee that all the fruits of all cultivars were collected exactly at the same stage of ripening.

Regarding the coloration of the persimmon cultivars, the color parameter $\mathrm{L} *$ ranged from 41.46 (Guiombo) to 61.07 (Taubaté), the color parameter $a^{*}$ varied from 10.50 (Guiombo) to 33.71 (Rama Forte) and the parameter $b^{*}$ color ranged from 
TABLE I

Average length (AL), average diameter (AD), unit weight (UW), total soluble solids (SS), total acidity (TA), firmness (Firm.), pH and color ( $\mathrm{L}^{*}, \mathrm{a}^{*}$ and $\left.\mathrm{b}^{*}\right)$ in persimmon cultivars.

\begin{tabular}{|c|c|c|c|c|c|c|c|c|c|c|}
\hline Cultivars & $\begin{array}{c}\mathrm{AL} \\
(\mathrm{mm})\end{array}$ & $\begin{array}{c}\mathrm{AD} \\
(\mathrm{mm})\end{array}$ & $\begin{array}{l}\text { UW } \\
\text { (g) }\end{array}$ & $\begin{array}{c}\text { SS } \\
\left({ }^{\circ} \text { Brix) }\right.\end{array}$ & $\begin{array}{l}\text { TA } \\
(\%)\end{array}$ & pH & $\begin{array}{c}\text { Firm. } \\
\text { (N) }\end{array}$ & $\mathbf{L}^{*}$ & $a^{*}$ & $\mathbf{b}^{*}$ \\
\hline Rama F. & $49.26^{\mathrm{c}}$ & $68.02^{\mathrm{a}}$ & $132.31^{\mathrm{a}}$ & $15.37^{\mathrm{b}}$ & $0.08^{\mathrm{a}}$ & $6.15^{\mathrm{a}}$ & $125.5^{\mathrm{ab}}$ & $55.12^{\mathrm{b}}$ & $33.71^{\mathrm{a}}$ & $49.10^{b}$ \\
\hline Mel & $58.05^{\mathrm{b}}$ & $64.45^{\mathrm{a}}$ & $114.66^{\mathrm{a}}$ & $16.40^{\mathrm{ab}}$ & $0.06^{\mathrm{a}}$ & $5.74^{\mathrm{a}}$ & $138.5^{\mathrm{a}}$ & $45.40^{\mathrm{c}}$ & $31.24^{\mathrm{a}}$ & $34.55^{\circ}$ \\
\hline Guiombo & $64.91^{\mathrm{ab}}$ & $59.35^{\mathrm{a}}$ & $111.21^{\mathrm{a}}$ & $18.23^{\mathrm{a}}$ & $0.08^{\mathrm{a}}$ & $5.97^{\mathrm{a}}$ & $97.95^{\mathrm{b}}$ & $41.46^{\mathrm{c}}$ & $10.50^{\mathrm{c}}$ & $22.01^{\circ}$ \\
\hline Taubaté & $69.25^{\mathrm{a}}$ & $66.50^{\mathrm{a}}$ & $162.66^{\mathrm{a}}$ & $16.10^{\mathrm{ab}}$ & $0.08^{\mathrm{a}}$ & $5.62^{\mathrm{a}}$ & $71.83^{b}$ & $61.07^{\mathrm{a}}$ & $27.75^{\mathrm{b}}$ & $63.30^{\circ}$ \\
\hline
\end{tabular}

Mean values with common letters in the same column indicate that there is no significant difference among samples $(\mathrm{p} \leq 0.05)$ from Tukey's mean test.

Total acidity: g citric acid/100 g f.w.

22.01 (Guiombo) to 63.30 (Taubate) (Table I). According to Table I, it can be seen that the Taubaté is the cultivar which has higher $\mathrm{L}^{*}(61.07)$ and $\mathrm{b}^{*}$ (63.30) values, this shows that this fruit has less intense black color, that is, a lighter fruit and has a more intense yellow color. Regarding the color parameter $\mathrm{a}^{*}$, the fruit of the cultivars Rama Forte and Mel, stood out due to their higher intensity of red color (33.71 and 31.24, respectively) when compared to the other cultivars. As noted in firmness, color may also reflect differences among cultivars and possible differences in the fruit maturation stage.

Total sugars ranged from $8.15 \mathrm{~g} / 100 \mathrm{~g}^{-1}$ (Taubaté) to $23.24 \mathrm{~g} / 100 \mathrm{~g}^{-1}$ (Rama Forte) (Table II). The Rama Forte is the cultivar with the highest acceptance potential for fresh consumption, due to higher total sugars content (Souza et al. 2012). According to Guedes et al. (2014), the accumulation of sugar in fruits plays value on its postharvest physiology. According to Table II, as to this glucose content in persimmon fruit, the cultivar Rama Forte stood presenting $15.88 \mathrm{~g} / 100 \mathrm{~g}^{-1}$ of glucose. Regarding the sucrose content in the different cultivars the Rama Forte and Guiombo cultivars showed larger amounts of sucrose (7.40 and 7.30 $100 \mathrm{~g} / \mathrm{g}^{-1}$, respectively) (Table II).

\section{Bioactive compounds and antioxidant activity}

Statistical analysis revealed that there was a statistical difference between the persimmon cultivars for the antioxidant activity and phenolic content ( $\mathrm{p} \leq 0.05$ ).According to Table II, the total content of phenolic compounds ranged from 113.28 to $188.49\left(\mathrm{mg} / 100 \mathrm{~g}^{-1}\right)$. Following the classification proposed by Vasco et al. (2008), the fruit, according to the content of phenolic compounds, are divided into three categories: low-phenols $(<100 \mathrm{mg} / 100$ $\left.\mathrm{g}^{-1}\right)$, an average content of phenols (100-500 $\mathrm{mg} / 100 \mathrm{~g}^{-1}$ ) and high content of phenols (> $500 \mathrm{mg}$ $\left.\mathrm{GAE} / 100 \mathrm{~g}^{-1}\right)$. According to this classification, all the persimmon cultivars can be classified as having an average concentration of phenols.

The antioxidant activity of different persimmon cultivars ranged from 4.12 the $15.13 \mathrm{mg} / 100 \mathrm{~g} \mathrm{~g}^{-1}$ (Mel and Guiombo, respectively). According to Tavarini et al. (2008), the genotype (cultivar) directly influences the total antioxidant capacity in fruits. The antioxidant capacity varies depending on the cultivar (Santos et al. 2013).

Regarding the antioxidant activity through the linoleic $\beta$ carotene/acid method it can be seen that the Guiombo cultivar presented with higher oxidation values (98.39\%) (Table II).According to Hassimoto et al. (2005), the antioxidant potential above $70 \%$ is considered to be great for the inhibition of lipid oxidation. The Guiombo and Mel cultivars reached antioxidant activity above $70 \%$, with high potential for inhibition of lipid oxidation. 
TABLE II

Total sugars, glucose, sucrose, phenolic, antioxidant activity dpph and $\beta$-carotene, $(\%$ the oxidation) in fruits of in different persimmon cultivars.

\begin{tabular}{|c|c|c|c|c|c|c|}
\hline Cultivars & Total sugars & Glucose & Sucrose & $\begin{array}{c}\text { Total } \\
\text { phenolics }\end{array}$ & $\begin{array}{c}\text { Antioxidant } \\
\text { capacity - DPPH }\end{array}$ & $\begin{array}{c}\text { Antioxidant } \\
\text { capacity - } \\
\text { B-carotene }\end{array}$ \\
\hline Rama F. & $23.24^{\mathrm{a}}$ & $15.88^{\mathrm{a}}$ & $7.4^{0 \mathrm{aa}}$ & $136.93^{\mathrm{b}}$ & $9.68^{\mathrm{b}}$ & $60.66^{\mathrm{c}}$ \\
\hline Mel & $10.0^{\mathrm{c}}$ & $13.43^{\mathrm{bc}}$ & $0.02^{\mathrm{b}}$ & $113.28^{\mathrm{c}}$ & $4.12^{\mathrm{c}}$ & $85.24^{\mathrm{b}}$ \\
\hline Guiombo & $20.15^{\mathrm{b}}$ & $12.26^{\mathrm{c}}$ & $7.30^{\mathrm{a}}$ & $155.40^{\mathrm{b}}$ & $15.13^{\mathrm{a}}$ & $98.39^{\mathrm{a}}$ \\
\hline Taubaté & $8.15^{\mathrm{c}}$ & $15.01^{\mathrm{ab}}$ & $0.02^{\mathrm{b}}$ & $188.49^{\mathrm{a}}$ & $12.07^{\mathrm{ab}}$ & $64.60^{\mathrm{c}}$ \\
\hline
\end{tabular}

Abbreviations: DPPH: 2-diphenyl-1-picryhydrazyl radical scavenging activity; GAE: gallic acid equivalent.

Total sugars, glucose and sucrosein g $100 \mathrm{~g}^{-1}$; Total phenolics (mg GAEs/100 g f.w.); Antioxidant capacity - DPPH (\% de sequestration); Antioxidant capacity - b-carotene (\% de oxidation).

Mean values with common letters in the same column indicate that there is no significant difference among samples $(p \leq 0.05)$ from Tukey's mean test.

TABLE III

Soluble Solids (SS), total acidity (TA), pH and color $\left(\mathrm{L}^{*}, \mathrm{a}^{*}\right.$ and $\left.\mathrm{b}^{*}\right)$ in persimmon juices.

\begin{tabular}{lcccccc}
\hline Cultivars & SS ( ${ }^{\circ}$ Brix) & TA $(\%)$ & pH & L* & $\mathbf{a}^{*}$ & $\mathbf{b}^{*}$ \\
\hline Rama Forte & $4.00^{\mathrm{a}}$ & $0.05^{\mathrm{a}}$ & $8.73^{\mathrm{b}}$ & $36.88^{\mathrm{b}}$ & $2.27^{\mathrm{ab}}$ & $7.81^{\mathrm{b}}$ \\
Mel & $3.00^{\mathrm{b}}$ & $0.03^{\mathrm{a}}$ & $9.20^{\mathrm{ab}}$ & $29.96^{\mathrm{b}}$ & $2.10^{\mathrm{b}}$ & $8.63^{\mathrm{b}}$ \\
Guiombo & $4.67^{\mathrm{a}}$ & $0.03^{\mathrm{a}}$ & $9.53^{\mathrm{ab}}$ & $49.29^{\mathrm{a}}$ & $5.49^{\mathrm{a}}$ & $29.89^{\mathrm{a}}$ \\
Taubaté & $4.00^{\mathrm{a}}$ & $0.03^{\mathrm{a}}$ & $9.93^{\mathrm{a}}$ & $34.18^{\mathrm{b}}$ & $2.22^{\mathrm{ab}}$ & $15.18^{\mathrm{b}}$ \\
\hline
\end{tabular}

Mean values with common letters in the same column indicate that there is no significant difference among samples $(\mathrm{p} \leq 0.05)$ from Tukey's mean test.

Total acidity: g citric acid/100 g f.w.

\section{PERSIMMON JUICE}

The average values and the average test of the physicochemical properties evaluated for the different persimmon juice formulations are shown in Table III. Except for the total acidity, all parameters were significant $p \leq 0.05$ for the juice prepared with the different persimmon cultivars.

The soluble solids content of the juice varied significantly among cultivars, ranging from 3.00 to $4.67{ }^{\circ}$ Brix (Mel and Guimbo cultivars, respectively). As was to be expected, the Guimbo cultivar was that which presented juice with highest soluble solids content. The soluble solids in the juice was well below that of the fruit, and can be explained because 30\% water was added to the pulp and the juice was prepared without the addition of sucrose.
Regarding the acidity, the $\mathrm{pH}$ of the juices ranged from 8.73 (Rama Forte) to 9.93 (Taubaté) and total acidity varied from 0.03 to $0.05 \mathrm{~g}$ citric acid / $100 \mathrm{~g}$ (Table III). According to Table III, it can be seen that the juice prepared with the Rama Forte cultivar had the lowest $\mathrm{pH}$, and was considered more acidic than the other formulations.

The total acidity results are according to previous permission juice studies where in the acidity found in the juice was 0.048. (González et al. 2015). In relation to the $\mathrm{pH}$, these values were higher than in the other study, which found a range varying from 6.04 to 6.11 Ergun and Ergun (2010).

Regarding color, the color parameter $\mathrm{L}^{*}$ ranged from 29.96 (Mel) to 49.29 (Guiombo), the color parameter $\mathrm{a}^{*}$ ranged from $2.10(\mathrm{Mel})$ to 5.49 (Guiombo) and the color parameter $b^{*}$ varied from 
7.81 (Rama Forte) to 29.89 (Guiombo) (Table III). According to Table III, it can be seen that with the cultivar Guiombo, juice had higher L*, a* and $b^{*}$ values, this means that this juice has low black color intensity, that is, a clearer juice and has higher yellow and red color intensity when compared to other formulations. The color of the juice obtained did not corroborate with the fresh fruit color results; this was possibly due to processing such as adding water to obtain the juice and possibly due to the reaction of the pigments with oxygen.

Through analysis of variance significant difference was verified among the juices obtained from different persimmon cultivars for all the evaluated sensory attributes $p \leq 0.05$. The mean scores and the mean test for the sensory characteristics evaluated in persimmon juice formulations are shown in Table IV. Figure 1 shows the three-way internal map, representing the consumer behavior, samples and acceptance attributes for the juice formulations. The number of factors in the PARAFAC model was chosen by the CORCONDIA value and was set to two $($ CORCONDIA $=72 \%)($ Bro and Kiers 2003, Nunes et al. 2011).

In general, the formulations of juices showed intermediate sensory acceptance for all sensory attributes evaluated, with average scores ranging from the hedonic terms "disliked slightly" and "liked very much" (Table IV).

According to the averages table (Table IV) and in accordance with the PARAFAC (Figure 1) it can be clearly seen the better consumer acceptance and preference for juice prepared with cultivar Rama Forte, and this cultivar differed from the others, presenting higher average scores for all sensory attributes, situated between the hedonic terms "liked slightly" and "liked very much". The other cultivars (Mel, Guiombo and Taubaté) were less acceptable and similar to each other for almost all sensory attributes evaluated (Table IV and Figure 1).
Aiming to correlate sensory acceptance with the physicochemical attributes of persimmon juice, the external preference map for the overall impression attribute is presented in Figure 2.

According to the external preference map (Figure 2) and according to the average scores of the physicochemical attributes of different persimmon juice formulations (Table III) one can notice that the juice prepared with the cultivar Guiombo characterized by having higher soluble solids and higher color intensity $\mathrm{L}^{*}, \mathrm{a}^{*}$ and $\mathrm{b}^{*}$, which reflects in a sweeter, clearer juice, with a more intense yellow / red coloration. It was expected that these characteristics would contribute to higher juice acceptance, but since that was not the result obtained, we can presume that other features of the juices are related to the sensory acceptance. According to Figure 2 and Table III, it appears that the juice prepared with the Rama Forte cultivar (most accepted, sensorially) characterized by having higher acidity, since the juice prepared from Taubaté cultivar showed higher $\mathrm{pH}$ values. Thus, there is an indication that the consumer has a preference for more acidic juices. The acidity, up to a certain level, may be desirable, mainly because of intensifying the characteristic flavor of the fruit.

\section{PERSIMMON JELLY}

The average values and the average test of the physicochemical properties evaluated for the different persimmon jelly formulations are shown in Table V. Except for soluble solids and color parameter $\mathrm{L}^{*}$, all parameters were significant $\mathrm{p} \leq$ 0.05 for the jelly made with different persimmon cultivars.

The soluble solids of the persimmon jelly ranged from 45.44 to $54.67{ }^{\circ}$ Brix (cultivars Guimbo and Mel respectively) (Table V). It was expected that the soluble solids content would not significantly differed because although the persimmon cultivars showed different soluble 
TABLE IV

Sensory characteristics of the persimmon juices obtained from different cultivars.

\begin{tabular}{lcccc}
\hline Formulations & Color & Taste & Consistency & Overall Liking \\
\hline Rama Forte & $7.5^{\mathrm{a}}$ & $6.7^{\mathrm{a}}$ & $6.3^{\mathrm{a}}$ & $6.9^{\mathrm{a}}$ \\
Mel & $4.9^{\mathrm{c}}$ & $5.6^{\mathrm{b}}$ & $5.5^{\mathrm{ab}}$ & $5.6^{\mathrm{b}}$ \\
Guiombo & $6.0^{\mathrm{b}}$ & $5.7^{\mathrm{b}}$ & $4.9^{\mathrm{b}}$ & $5.6^{\mathrm{b}}$ \\
Taubaté & $6.5^{\mathrm{b}}$ & $6.1^{\mathrm{ab}}$ & $5.0^{\mathrm{b}}$ & $6.0^{\mathrm{b}}$ \\
\hline
\end{tabular}

Mean values with common letters in the same column indicate that there is no significant difference among samples $(\mathrm{p} \leq 0.05)$ from Tukey's mean test.

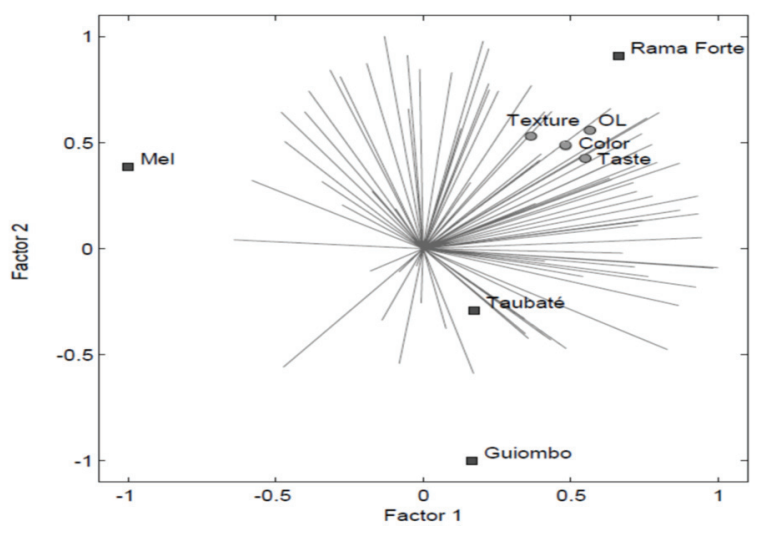

Figure 1 - Three-way internal preference maps for color, taste, consistency and overall liking obtained for the persimmon juice formulations.

*Consumers are represented by vectors, samples by squares and acceptance attributes by circles.

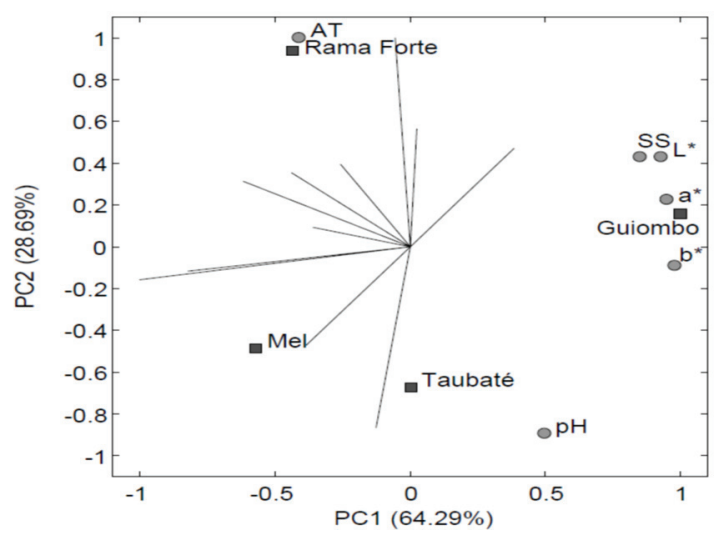

Figure 2 - External preference mapping for overall liking for the persimmon juices. Consumers are represented by vectors, samples by squares and physicochemical and texture attributes by circles.

*SS, Soluble Solids; TA, Total acidity. solids, during the preparation of the jelly the final brix degree was fixed.

Regarding the acidity, the $\mathrm{pH}$ of the jellies ranged from 3.67 (Taubaté) to 4.60 (Mel) and total acidity ranged from 0.29 (Guiombo) to $0.43 \mathrm{~g}$ of citric acid / 100g (Taubaté) (Table V). The jellies prepared from the cultivar Mel presented the highest $\mathrm{pH}$ value (4.60); the jellies from the Taubaté cultivar showed the highest acidity $(0.43 \mathrm{~g}$ citric acid / $100 \mathrm{~g}$ ). Although the fruits showed no significant difference in acidity and the amount of citric acid added was the same in all formulations, the difference observed between the jellies is due to processing and intensity of the reactions that occur during cooking. A common reaction in the preparation of jellies is the conversion of organic acids into sugars. (Tosun et al. 2008).

Regarding color, the color parameter $\mathrm{a}^{*}$ ranged from 0.58 to 1.44 and the color parameter $b^{*}$ ranged from 5.55 to 15.07 (Table V). Regarding the color parameter $\mathrm{a}^{*}$, the jelly obtained from cultivar Taubaté, stands out due to its higher yellow intensity (1.44) when compared to other formulations. For the color parameter $b^{*}$, the jelly obtained from cultivar Rama Forte stood out with the highest red intensity (15.07). As for the color parameter L*, no significant difference was verified among the jellies prepared from the different persimmon cultivars, and the range of variation was 32.38 to 40.27 . Compared to fresh fruit, yellow/red color of the jelly is less intense and is darker, possibly because 
TABLE V

Soluble Solids (SS), total acidity (TA), pH and color $\left(L^{*}, a^{*}\right.$ and $\left.b^{*}\right)$ in persimmon jellies.

\begin{tabular}{|c|c|c|c|c|c|c|}
\hline Cultivars & SS ( $\left({ }^{\circ}\right.$ Brix) & ТА (\%) & pH & $\mathbf{L}^{*}$ & $a^{*}$ & $\mathbf{b}^{*}$ \\
\hline Rama Forte & $46.00^{\mathrm{a}}$ & $0.31^{\mathrm{b}}$ & $4.17^{b}$ & $39.94^{\mathrm{a}}$ & $0.72^{b}$ & $15.07^{\mathrm{a}}$ \\
\hline Mel & $54.67^{\mathrm{a}}$ & $0.38^{\mathrm{b}}$ & $4.60^{\mathrm{a}}$ & $36.20^{\mathrm{a}}$ & $0.74^{b}$ & $5.55^{\mathrm{b}}$ \\
\hline Guiombo & $45.44^{\mathrm{a}}$ & $0.29^{\mathrm{b}}$ & $3.87^{\mathrm{c}}$ & $40.27^{\mathrm{a}}$ & $0.58^{\mathrm{b}}$ & $8.33^{\mathrm{b}}$ \\
\hline Taubaté & $53.67^{\mathrm{a}}$ & $0.43^{\mathrm{a}}$ & $3.67^{\mathrm{c}}$ & $32.38^{\mathrm{a}}$ & $1.44^{\mathrm{a}}$ & $6.63^{\mathrm{b}}$ \\
\hline
\end{tabular}

Mean values with common letters in the same column indicate that there is no significant difference among samples $(\mathrm{p} \leq 0.05)$ from Tukey's mean test.

Total acidity: g citric acid/100 g f.w.

of the concentration and the reactions that occur during the heating, such as the Maillard reaction.

The average values and the average test of the rheological properties evaluated for the different persimmon jelly formulations are shown in Table VI. A significant difference was observed $p \leq 0.05$ for all rheological parameters evaluated, except for springiness.

Texture profile analysis (TPA) is a method for evaluating sensory properties. The test consists of compressing the food (study sample) twice in a reciprocating motion to mimic the action of the mandible; a first compression and relaxation followed by a second compression are performed during testing. This test yields a graph of force versus time from which the texture parameters are calculated. (Honikel 1998, Lau et al. 2000, Bourne 2002, Herrero et al. 2007).

The hardness measures the force required to achieve a certain deformation; adhesiveness is the amount of force to simulate the work necessary to overcome the attractive forces between a surface and the food surface in contact with it; gumminess is energy required to disintegrate a semi-solid food to the point of being swallowed; chewiness is the energy required to chew solid food to the point of being swallowed; springiness measures the rate at which the deformed material returns to its original condition after the removal of the deforming force and cohesiveness is the extent to which the material can be stretched before irreversibly breaking.
(Friedman et al. 1963, Bourne 1968, Van Vliet 1991, Huang et al. 2007).

The jelly obtained from the Mel cultivar had the highest hardness $(3.748 \mathrm{~N})$, higher adhesiveness modulus (7.878) and greater gumminess $(1.280 \mathrm{~N})$ and chewiness (1.245). The jelly obtained from the Rama Forte cultivar characterized by having the highest cohesiveness value (0.579). As such, the jelly obtained by Mel cultivar characterized as a more rigid, firm, sticky, adhesive and elastic jelly.

Several factors may explain the variation in texture among the jellies prepared from different persimmon varieties; among them the amount of sugar naturally present in each cultivar, $\mathrm{pH}$, acidity and soluble pectin content are factors that may influence the gelling and therefore the texture of the end product (Souza et al. 2014). In addition, other factors such as the moisture content and the chemical composition of the fruit affect the texture profile, as it may influence the cooking time, yield, and thus the moisture content of the end product (Jackix 1988, Gava 1998, Lofgren and Hermansson 2007).

Through analysis of variance a significant difference was verified among the jellies obtained from different persimmon cultivars as to taste, consistency and overall liking $\mathrm{p} \leq 0.05$. The mean scores and the mean test for the sensory characteristics evaluated in persimmon jelly formulations are shown in Table VII. Figure 3 shows the three-way internal map, representing the consumer behavior, samples and acceptance 
TABLE VI

Texture parameters of the persimmon jellies obtained from different cultivars.

\begin{tabular}{llccccc}
\hline Cultivar & Hard & Adhe & Spr & Coh & Gum & Chew \\
\hline Rama Forte & $0.154^{\mathrm{c}}$ & $-1.167^{\mathrm{a}}$ & $0.980^{\mathrm{a}}$ & $0.579^{\mathrm{a}}$ & $0.089^{\mathrm{c}}$ & $0.088^{\mathrm{c}}$ \\
Mel & $3.748^{\mathrm{a}}$ & $-7.787^{\mathrm{b}}$ & $0.972^{\mathrm{a}}$ & $0.341^{\mathrm{c}}$ & $1.280^{\mathrm{a}}$ & $1.245^{\mathrm{a}}$ \\
Guiombo & $0.369^{\mathrm{c}}$ & $-1.556^{\mathrm{a}}$ & $0.977^{\mathrm{a}}$ & $0.464^{\mathrm{b}}$ & $0.170^{\mathrm{c}}$ & $0.166^{\mathrm{c}}$ \\
Taubaté & $2.550^{\mathrm{b}}$ & $-5.409^{\mathrm{ab}}$ & $0.958^{\mathrm{a}}$ & $0.329^{\mathrm{c}}$ & $0.843^{\mathrm{b}}$ & $0.807^{\mathrm{b}}$ \\
\hline
\end{tabular}

Mean values with common letters in the same column indicate that there is no significant difference among $(p \leq 0.05)$ from Tukey's mean test.

Hard - Hardness (N); Adhe - Adhesiveness (N/s); Spr - Springiness; Coh - Cohesiveness; Gum - Gumminess (N); Chew Chewiness.

TABLE VII

Sensory characteristics of the persimmon jellies obtained from different cultivars.

\begin{tabular}{lcccc}
\hline Formulations & Color & Taste & Consistency & Overall Liking \\
\hline Rama Forte & $7.1^{\mathrm{a}}$ & $7.3^{\mathrm{a}}$ & $7.2^{\mathrm{a}}$ & $7.3^{\mathrm{a}}$ \\
Mel & $6.7^{\mathrm{a}}$ & $6.2^{\mathrm{b}}$ & $5.0^{\mathrm{b}}$ & $5.6^{\mathrm{b}}$ \\
Guiombo & $7.1^{\mathrm{a}}$ & $7.2^{\mathrm{a}}$ & $7.2^{\mathrm{a}}$ & $7.2^{\mathrm{a}}$ \\
Taubaté & $6.5^{\mathrm{a}}$ & $6.3^{\mathrm{b}}$ & $5.0^{\mathrm{b}}$ & $5.8^{\mathrm{b}}$ \\
\hline
\end{tabular}

Mean values with common letters in the same column indicate that there is no significant difference among samples $(\mathrm{p} \leq 0.05)$ from Tukey's mean test.

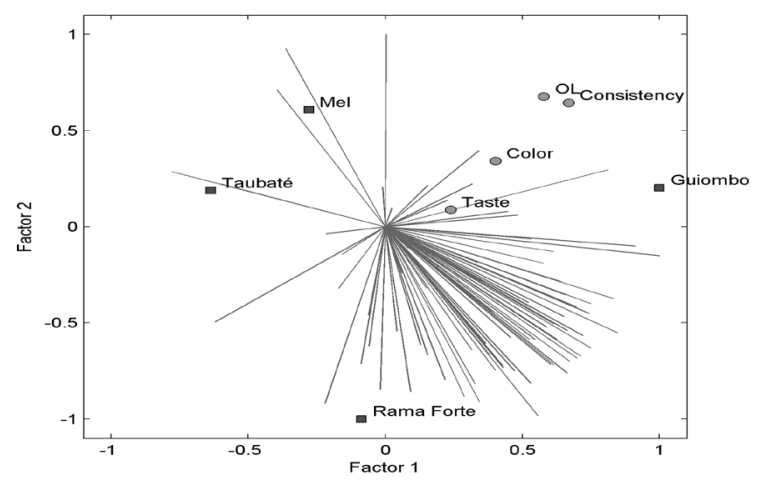

Figure 3 - Three-way internal preference maps for color, taste, consistency and overall liking obtained for the persimmon jelly formulations.

*Consumers are represented by vectors, samples by squares and acceptance attributes by circles.

attributes for the jelly formulations. The number of factors in the PARAFAC model was chosen by the CORCONDIA value and was set to two $($ CORCONDIA $=64 \%)($ Bro and Kiers 2003, Nunes et al. 2011).

In general the jelly formulations showed good sensory acceptance, higher than the persimmon juice, for all sensory attributes evaluated, with average scores ranging from the hedonic terms "not liked/nor disliked" and "liked very much" (Table VII).

According to the average table (Table VII) and according to the PARAFAC (Figure 3 ) it can clearly see the consumer acceptance and preference for jelly prepared with Rama Fort and Guiombo cultivars, and these jellies differentiated from the others showing higher average scores for all sensory attributes, situated between the hedonic terms "liked moderately" and "liked very much". The jelly obtained from the other cultivars (Mel and Taubaté) were less acceptable and similar to each other for almost all sensory attributes evaluated (Table V and Figure 3). It is important to emphasizes that jellies developed with these cultivars obtained lower scores, especially for the consistency attribute, which may have resulted in the lowest overall liking score.

Aiming to correlate sensory acceptance with the physicochemical and rheological attributes of persimmon jellies, the external preference map 
for the overall impression attribute is presented in Figure 4.

According to the external preference map (Figure 4) and according to the average scores of physicochemical and rheology attributes for different persimmon jelly formulations (Table IV and Table V, respectively) it can be seen that the jellies elaborated with Mel and Taubaté cultivars, less accepted formulations, characterized by presenting higher hardness, adhesiveness, gumminess, chewiness and higher soluble solids. Furthermore, the jelly prepared with the cultivar Taubaté characterized as being more acidic and having a higher red color intensity and Mel, due to its higher $\mathrm{pH}$ (Figure 4, Tables IV and V). The jellies elaborated with the Guiombo and Rama Forte cultivars, which were the most accepted formulations, characterized as having greater cohesiveness and greater intensity of $\mathrm{L}^{*}$ and $\mathrm{b}^{*}$ color, which reflects in a clearer and more intense yellow-colored jelly. Thus, there is an indication that the consumer has a preference for softer or less firm jellies, less sweet, lighter and more intense yellow color.

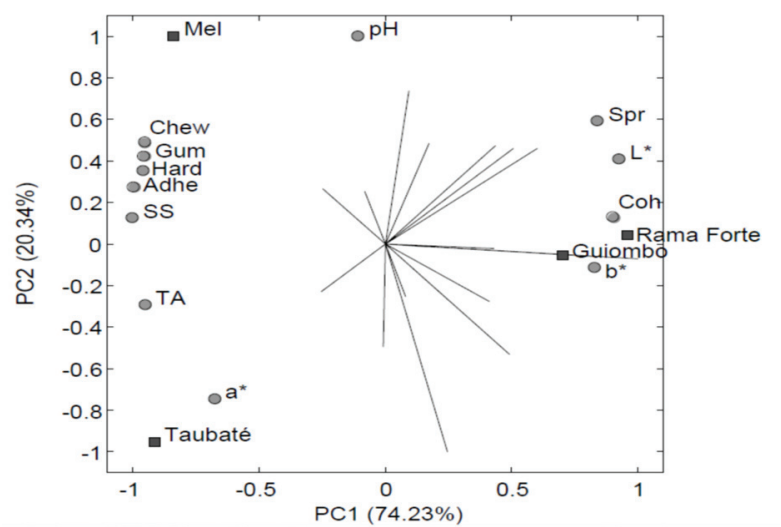

Figure 4 - External preference mapping for overall liking for the persimmon jellies. Consumers are represented by vectors, samples by squares and physicochemical and texture attributes by circles.

*SS, Soluble Solids; TA, Total acidity; Hard, Hardness $(\mathrm{N})$; Adhe, Adhesiveness (N/s); Sprin, Springiness; Cohe, Cohesiveness; Gummi, Gumminess (N); Chew, Chewiness.
PERSIMMON PROCESSING POTENTIAL

From the sensory acceptance results it was recognized that persimmon processing, in the form of juices and mainly in the form of jelly, is feasible. Sensorially speaking, for juice elaboration the most suitable cultivar is Rama Forte, and for jelly preparation the most suitable cultivars are Rama Forte and also the Guiombo. The juice and jelly formulations made with the other cultivars had lower average acceptance scores, but that does not mean impossibility of use, as adjustments in the process could change the undesirable characteristics.

It is important to emphasize that the cultivar Rama Forte, which was the most suitable for the preparation of juice and one of the most suitable for the preparation of jelly, with high processing potential, is considered unsuitable for fresh consumption because this cultivar is astringent and features high soluble tannin levels (Edagi et al. 2009, Gardin et al. 2012).

The largest Brazilian persimmon producer state is São Paulo, reaching $60 \%$ of the national production. Of this total, $50 \%$ are the cultivar 'Rama Forte', 19\% 'Guiombo', 15\% 'Fuyu', 14\% 'Taubaté' and $2 \%$ others (Camargo Filho et al. 2003, Terra et al. 2014). The cultivars that have the highest productivity and adaptability in Brazil (Rama Forte and Guiombo) were exactly those most suitable for processing.

\section{CONCLUSIONS}

The different studied persimmon cultivars (Rama Forte, Mel, Guiombo and Taubaté) had different physical and physicochemical characteristics which resulted in juices and jellies with different physicochemical, rheological and sensory characteristics. The consumer prefers a more acidic persimmon juice and a less firm or softer persimmon jelly, less sweet, clearer with a more intense yellow color. Based on sensory acceptance and productivity/adaptability of persimmon crop in 
Brazil, the most suitable persimmon cultivars for processing are Rama Forte and Guiombo.

\section{ACKNOWLEDGMENTS}

The authors would like to thank Fundação de Amparo à Pesquisa do Estado de Minas Gerais (FAPEMIG), Conselho Nacional de Desenvolvimento Científico e Tecnológico (CNPq) and Coordenação de Aperfeiçoamento de Pessoal de Nível Superior (CAPES) for the financial support.

\section{REFERENCES}

ACOSTA O, VÍQUEZ F AND CUBERO E. 2008. Optimization of low calorie mixed fruit jelly by response surface methodology. Food Qual Prefer 19: 79-85.

ALVES G, VERBISKI FS, MICHAELIDES TJ AND MIO LLM. 2011. First report of Pestalotiopsisdiospyri causing canker on persimmon trees. Rev Bras Frutic 33: 10191022.

BLUM J, HOFFMANN FB, AYUB RA, JUNG DL AND MALGARIM MB. 2008. Uso de cera na conservação póscolheita de caqui cv 'Giombo'. Rev Bras Frutic 30: 830-833.

BOURNE MC. 1968. Texture profile of ripening pears. J Food Sci 33: 223-226.

BOURNE MC. 2002. Food texture and viscosity: concept and measurement. New York: Academic Press.

BRACKMANN A, SCHORR MRW, GASPERIN AR, VENTURINI TL AND PINTO JAV. 2013. Controle da maturação de caqui 'Fuyu' com aplicação de aminoetoxivinilglicina e 1-metilciclopropeno. Rev Bras Frutic 35: 953-961.

BRAND-WILLIAMS W, CUVELIER ME AND BERSET C. 1995. Use of a free-radical method to evaluate antioxidant activity. Food Scitechnol 28: 25-30.

BRO R. 1997. PARAFAC. Tutorial and applications. Chemom Intell Lab Syst 38: 149-171.

BRO R AND KIERS H. 2003. A new efficient method for determining the number of components in PARAFAC models. J Chemom 17: 274-286.

BUENO SCS, PIO R AND WIECHMANN CJS. 2014. Cultivo do caquizeiro. In: Pio R (Ed), Cultivo de fruteiras de clima temperado em regiões subtropicais e tropicais. $1^{\text {a }}$ ed., Lavras-MG: Editora UFLA 1: 250-295.

BUTT MS, SULTAN T, AZIZ M, NAZ A AND AHMED W. 2015. Persimmon (Diospyros kaki L.) Fruit: Hidden Phytochemicals And Health Claims. Excli Journal 14: 542-561.
CAMARGO FILHO WP, MAZZEI AR AND ALVES HS. 2003. Mercado de caqui: Variedades, estacionalidade e preços. Inf Econ 33: 81-87.

CAMPO-DALL'ORTO FA, OJIMA M, BARBOSA W AND ZULLO MAT. 1996. Novo processo de avaliação da adstringência dos frutos no melhoramento do caquizeiro. Bragantia 55: 237-243.

DEL BUBBA M, GIORDANI E, PIPPUCCI L, CINCINELLI A AND CHECCHINI L. 2009. Changes in tannins, ascorbic acid and sugar content in astringent persimmons during on-tree growth and ripening and in response to different postharvest treatments. J Food Compos Anal 22: 668-677.

DUARTE-ALMEIDA, JM, SANTOS RJ, GENOVESE MI AND LAJOLO FM. 2006. Avaliação da atividade antioxidante utilizando sistema $\beta$-caroteno/ácido linoléico e método de seqüestro de radicais dpph. Ciên Tecno Alim 26: 446-452.

EDAGI FK AND KLUGE RA. 2009. Remoção de adstringência de caqui (Diospyros kaki L.): um enfoque bioquímico, fisiológico e tecnológico. Ciênc Rural 39: 585-594.

EDAGI FK, SESTARI I, TERRA FAM, CHIOU DG AND KLUGE RA. 2009. Effect of Ripening Stage on Astringency Removal of 'Rama Forte' Persimmon. Acta Hortic 833: 269-274.

ERGUN M AND ERGUN N. 2010. Extending Shelf Life of Fresh-Cut Persimmon By Honey Solution Dips. J Food Process Preserv 34: 2-14.

FRIEDMAN HH, WHITNEY JE AND SZCZESNIAK AS. 1963. The texturometer-a new instrument for objective texture measurement. J Food Sci 28: 390-396.

GARDIN JPP, ARGENTA LC, SOUZA ELS, ROMBALDI CV AND SOUZA ALK. 2012. Qualidade de caqui 'Rama Forte' após armazenamento refrigerado, influenciada pelos tratamentos 1-Mcp E/Ou Co 2 Rev Bras Frutic 34: 10431050.

GAVA AJ. 1998. Princípios de tecnologia de alimentos. 2a ed., São Paulo: Nobel P, 284 p.

GENNADIOS A, WELLER CL, HANNA MA AND FRONING G. 1996. Mechanical and barrier properties of egg albumen films. J Food Sci 61: 585-589.

GONZÁLEZ E, VEGARA E, MART N, VALERO M AND SAURA D. 2015. Physicochemical Characterization of Pure Persimmon Juice: Nutritional Quality and Food Acceptability. J Food Sci 80: 532-539.

GUEDES MNS, MARO LAC, ABREU CMP, PIO R AND PATTO LS. 2014. Composição química, compostos bioativos e dissimilaridade genética entre cultivares de amoreira (Rubus spp.) cultivadas no Sul de Minas Gerais. Rev Bras Frutic 36: 206-213.

HASSIMOTO NM, GENOVESE MI AND LAJOLO FM. 2005. Antioxidant activity of dietary fruits, vegetables, and 
commercial frozen fruit pulps. J Agric and Food Chem 53: 2928-2935.

HERRERO AM, ORDÓNEZ JA, AVILA R, HERRANZ B AND HOZ L. 2007. Breaking strength of dry fermented sausages and their correlation with texture profile analysis (TPA) and physicochemical characteristics. Meat Sci 77: 331-338.

HONIKEL KO. 1998. Reference methods for the assessment of physical characteristics of meat. Meat Sci 49: 447-457.

HUANG M, KENNEDY JF, LI B, XU X AND XIE BJ. 2007. Characters of rice starch gel modified by gellan, carrageenan and glucomannan: a texture profile analysis study. Carbohydr Polym 69: 411-418.

IAL - INSTITUTO ADOLFO LUTZ. 2005. Normas Analíticas do Instituto Adolfo Lutz. 2005. São Paulo: Instituto.

ITO S. 1971. The persimmon. In: Hulme AC (Ed), The biochemistry of fruits and their products. Academic Press 2: 281-301.

JACKIX MH. 1988. Doces, geleias e frutas em calda. São Paulo: Ícone, 158 p.

JIMÉNEZ-SÁNCHEZ C, LOZANO-SANCHEZ J, MARTI N, SAURA D AND VALERO M. 2015. Characterization of polyphenols, sugars, and other polar compounds in persimmon juices produced under different technologies and their assessment in terms of compositional variations. Food Chem 182: 282-291.

LAU MH, TANG J AND PAULSON AT. 2000. Texture profile and turbidity of gellan/gelatin mixed gels. Food Res Int 33: 665-671.

LEE JH, LEE YB, SEO WD, KANG AT AND LIM JW. 2012. Comparative Studies of Antioxidant Activities and Nutritional Constituents of Persimmon Juice (Diospyros kaki L. cv. Gapjubaekmok). Prev Nutr Food Sci 17: 141-151.

LOFGREN C AND HERMANSSON AM. 2007. Synergistic rheological behavior of mixed HM/LM pectin gels. Hydrocoll 21: 480-486.

MARTINELI M, ALVES AAR, FIGUEIREDO GM, REZENDE CM AND FONSECA MJO. 2013. Caqui cv. 'Mikado': análise de compostos voláteis em frutos adstringentes e destanizados. Ciênc Rural 43: 1516-1521.

MARTÍNEZ-CALVO J, NAVAL M, ZURIAGA E, LLÁCER G AND BADENES ML. 2013. Morphological characterization of the IVIA persimmon (Diospyros kaki Thunb.) germplasm collection by multivariate analysis. Genet resourcropevol 60: 233-241.

MARTINS FPAND PEREIRA FM. 1989. Cultura do caquizeiro. Jaboticabal. FUNEP. Editora Legis Lumma, 71 p.

NELSON NAA. 1944. Photometric adaptation of Somogy method for the determination of glucose. J Biolog Chem 153: 375-384.

NUGRAHERI M AND RAHMAWATI F. 2013. Potencial of yospirus Khaki Baverage as Sources of Natural Antioxidant. Pakistan J Nutrition 12: 620-627.
NUNES CA, PINHEIRO ACM AND BASTOS SC. 2011. Evaluating consumer acceptance tests by three-way internal preference mapping obtained by parallel factor analysis (PARAFAC). J Sens Stud 26: 167-174.

PAIVA MC, MANICA I, FIORAVANÇO JC AND KIST H.1997. Caracterização química dos frutos de quatro cultivares e de duas seleções de goiabeira. Rev Bras Frutic 19: 57-63.

PINHEIRO ACM, NUNES CA AND VIETORIS V. 2013. SensoMaker: a tool for sensorial characterization of food products. Ciênc Agrotec 37: 199-201.

PIO R, SCARPARE FILHO JÁ AND MOURÃO FILHO FAA. 2003. A cultura do caquizeiro. Piracicaba: ESALQ/ USP, 35 p. (Série Produtor Rural 23).

SANTOS CM, ABREU CMP, FREIRE JM AND CORRÊA AD. 2013. Atividade antioxidante de frutos de quatro cultivares de pessegueiro. Rev Bras Frutic 35: 339-344.

SILVA PSL, SA WR, MARIGUELE KH, BARBOSA APR AND OLIVEIRA OF. 2002. Distribuição do teor de sólidos solúveis totais em frutos de algumas espécies de clima temperado. Rev Caatinga 15: 19-23.

SINGLETON VL, ORTHOFER R AND LAMUELARAVENTOS RM. 1999. Analysis of total phenols and other oxidation substrates and antioxidants by means of Folin-Ciocalteu reagent. Methods Enzymol 299: 152-178.

SOUZA VR, PEREIRA PAP, PINHEIRO ACM, LIMA LCO AND PIO R. 2014. Analysis of the subtropical blackberry cultivar potential in jelly processing. J Food Sci 79: 17761781.

SOUZA VR, QUEIROZ PAP, BORGES F, CARNEIRO SV AND SOUZA JD. 2012. Determination of bioactive compounds, antioxidant activity and chemical composition of Cerrado Brazilian fruits. Food Chem 134: 381-386.

STONE HS AND SIDEL J. 1993. Sensory evaluation practices, San Diego, Calif.: Academic Press.

TAVARINI S, DEGL'INNOCETI E, REMORINI D, MASSAI R AND GUIDI L. 2008. Preliminary characterisation of peach cultivars for their antioxidant capacity. Inter J Food Sci and Technol 43: 810-815.

TERRA FAM, EDAGI FK, SASAKI FFC, FRASSETTO FILHO ME AND SILVA MM. 2014. Aplicação do 1-metilciclopropeno e sua influência no processo de remoção da adstringência com etanol em caqui 'Giombo' refrigerado. Ciênc Rural 44: 210-216.

TESSMER MA, KLUGE RA AND GLÓRIA BA. 2014. The accumulation of tannins during the development of 'Giombo' and 'Fuyu' persimmon fruits. Sci Hortic 172: 292-299.

TOSUN I, USTUN NS AND TEKGULER B. 2008. Physical and chemical changes during ripening of blackberry fruits. Sci Agri 65: 87-90.

VAN VLIET T. 1991. Terminology to be used in cheese rheology. Int Dairy Fed 268: 5-15. 
VASCO C, RUALES J AND KAMAL-ELDIN A. 2008. Total phenolic compounds and antioxidant capacities of major fruits from Ecuador. Food Chem 111: 816-823.

VEBERIC RJ, JURHAR M, MIKULIC-PETKOVSEK F, STAMPAR F AND SCHMITZER V. 2010. Comparative study of primary and secondary metabolites in 11 cultivars of persimmon fruit. (Diospyros kaki L.) Food Chem 119: $477-483$.
VIEITES RL, PICANÇO NFM AND DAIUTO ER. 2012.

Radiação Gama na conservação de caqui 'Giombo', destanizado e frigo armazenado. Rev Bras Frutic 34: 719726.

WAKELING IN AND MACFIE HJH. 1995. Designing consumer trials balanced for first and higher orders of carry-over effect when only a subset of $k$ samples from $t$ may be tested. Food Qual Prefer 6: 299-308. 